\title{
Impact of COVID-19 on access to justice and documents
}

\section{On the application of EU law, the Charter of Fundamental Rights and the possibility of non-jurisdictional remedies}

\section{Laura Dorneanu $^{1}$ · Julius Malka ${ }^{2}$ Laura Coeckelberghs ${ }^{3}$}

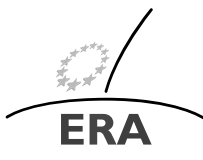

EUROPÄISCHE RECHTSAKADEMIE ACADEMY OF EUROPEAN LAW ACADEMIE DE DROIT EUROPEEN ACCADEMIA DI DIRITTO EUROPEO TRIER - TREVES - TREVIRI

\begin{abstract}
The COVID-19 outbreak has created an unprecedented impact on the functioning of access to justice and access to documents. New ways of administering justice were introduced, but the outbreak nevertheless caused severe delays in proceedings and even shut down courts in several members states. The impact on fundamental rights was far-reaching.

This article will examine the ways in which EU law can intervene in such cases. Does it provide EU citizens with means to enforce their rights under EU law? Further, national COVID-19 measures will be analysed in light of primary and secondary EU legislation, and will include an application of the Charter of Fundamental Rights and the possibility of non-jurisdictional remedies.
\end{abstract}

Keywords Covid 19 - Fundamental rights - access to justice - Remote hearings · Proportionality · Non-jurisdictional remedies · ADR · Charter of Fundamental Rights $\cdot$ EU law

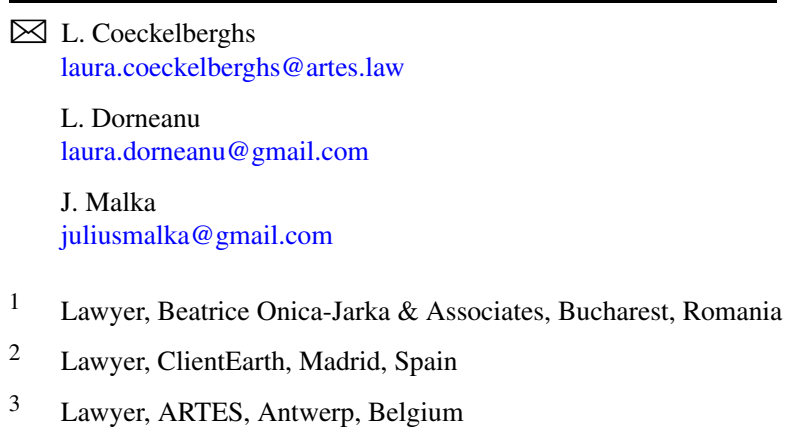




\section{Introduction}

With the spread of the COVID-19 virus, Member States of the European Union (EU) needed to look at other ways to safeguard the right to an effective remedy and fair trial, and found a solution in the implementation of remote access to justice. Soon various human rights advocates expressed their concerns about the impact of such a solution on fundamental rights and feared that remote access to justice would become a permanent solution in the future in light of cost and efficiency advantages [22].

Given the global nature of the pandemic, there might however be a way for the EU to intervene in this issue at a supranational level, not only in order to assist the Member States themselves, but also to support the nationals of each of those Member States in case the situation becomes threatening to their rights as an EU citizen.

In what follows, we will take a closer look at this possible power that the EU has within the EU legal framework, and decide whether the current situation has any link with EU law. Can it force the Member States to take or refrain from certain actions relating to the organisation of proceedings? Secondly, if EU law applies, the provisions of the Charter of Fundamental Rights (Charter) apply and national restrictions will have to be proportionate. Finally, we will turn to the possibility of affected parties to rely on non-jurisdictional measures. If there are concerns about remote access to justice, there might instead be different ways to preserve rights as EU citizens.

\section{The application of EU law to national measures taken in light of the COVID-19 crisis}

In 2007 the Treaty of Lisbon replaced the well-known Three-Pillar System by a more harmonised and integrated model merging the different pillars, including the former Justice and Home Affairs pillar [19]. The European integration process hereby came to a point where the Union received a single legal personality with clear values, aims and objectives stipulating that "the Union is founded on the values of human dignity, freedom, democracy, equality, the rule of law and respect for human rights (...)" (Article 2 of the Treaty on European Union (TEU)). Furthermore, it introduced the area of freedom, security and justice (AFSJ) determining that the Union shall "constitute an area of freedom, security and justice with respect for fundamental rights and the different legal systems and traditions of the Member States" including access to justice, in particular "through the principle of mutual recognition of judicial and extrajudicial decisions" in civil and criminal matters (Article 67 of the Treaty on the Functioning of the European Union (TFEU) juncto Article 3 TEU).

\subsection{The competence of the EU in civil and criminal matters having cross-border implications}

In light of these values and objectives, the Union has in accordance with Articles 81 and 82 TFEU, the power to serve the aim of developing judicial cooperation in civil and criminal matters having cross-border implications, by adopting measures for the approximation of the laws and regulations of the Members States. In accordance with 
the ordinary legislative procedure, the Union is able to - except in relation to family law issues - adopt measures aimed at (i) mutual recognition and enforcement of judgments and decisions, (ii) eliminating obstacles to the proper functioning of proceedings, (iii) effective access to justice, and (iv) in criminal cases, the establishment of minimum rules concerning the rights of individuals in criminal proceedings and the rights of victims of crime.

In cases with a cross-border dimension it thus becomes clear that the national measures taken in light of the COVID-19 pandemic are subject to possible EU legal review when the EU has adopted measures pursuant to Articles 81 and 82 TFEU. In relation to cross-border cooperation in criminal matters, these EU measures mostly concern measures like the European Arrest Warrant (EAW)-regime, extradition from/to third states, the European Investigation Order, mutual legal assistance, transfer of sentenced people, freezing orders, confiscation orders and Joint Investigation Teams [17].

With COVID-19 some of these measures and forms of cooperation obviously suddenly became postponed or non-prioritised due to the remote working requirements and travel or border restrictions, causing severe delays, prolongation of detention or even inactivity in some Member States. Some Member States already recognised that prolonging the detention would be in conflict with the principle of proportionality under the EAW [27] and released certain people from detention putting them under alternative surveillance methods (see Article 12 EAW Framework Decision) [20]. However, others like the United Kingdom's High Court ruled instead that ongoing detention was lawful even if extradition could temporarily not take place due to COVID-19, with reference to the humanitarian reasons-clause in Article 23 (4) of the EAW Framework Decision [21].

Coming back to Articles 81 and 82 TFEU, it can be mentioned that these articles were recently also invoked in a preliminary question referred to the European Court of Justice (CJEU) by an Italian Justice of the Peace. An Italian judge wondered whether these articles in conjunction with the rights of the Charter, precluded COVID-19 related national legislation declaring a state of national health emergency and paralysis of civil and criminal justice.

Through an order of 10 December 2020, the CJEU however declared the preliminary question manifestly inadmissible. The Court recalled that for these EU law provisions to apply, the dispute in the main proceedings should have transnational implications, namely any connection with the provisions of the EU Treaties or a situation where the national court would have to apply any of the EU provisions to solve the dispute [15]. In this case, the dispute concerned a damages claim relating to a traffic accident whereby the Italian court did not provide any clear cross-border links with EU law provisions, nor referred to any applicable national provisions for such claim for damages, and instead merely confined itself to making general considerations on the impact of COVID-19 on the judicial system. The mere statement that most of the national law provisions applicable to the case resulted from the transposition of Union law without any further clarification or precision, was held to be insufficient.

COVID-19 related preliminary questions to the CJEU will therefore likely only be successful if the underlying national proceedings have a clear EU link in the form of 
application of (implemented) EU law provisions or EU measures having cross-border implications, e.g. the EAW-regime.

\subsection{The competence of the EU in criminal proceedings after the Roadmap of 2009}

Besides the application of EU law in cases with a cross-border dimension, reference can also be made to the Resolution on a Roadmap adopted by the Justice Council on 30 November 2009. In this Roadmap the Council called for the creation of certain procedural rights of suspected or accused persons in criminal proceedings in relation to: translation and interpretation (measure A), information on rights and information about the charges (measures B), legal advice and legal aid (measure C), communication with relatives, employers and consular authorities (measure D), and special safeguards for suspected or accused persons who are vulnerable (measure E) [3].

The European Council subsequently made this Roadmap part of the Stockholm Programme and in the years that followed, six Directives saw the light of day [18]: Directive 2010/64/EU on the right to interpretation and translation in criminal proceedings, Directive 2012/13/EU on the right to information in criminal proceedings, Directive 2013/48/EU on the right of access to a lawyer, Directive 2016/1919/EU on the right to legal aid, Directive 2016/343/EU on the right of the presumption of innocence and to be present at trial, and Directive 2016/800/EU on procedural safeguards for children suspected of accused in criminal proceedings [25].

Based on the supremacy of EU law and the principle of direct effect [8,9], Member States will - even in times of COVID-19 - have to make sure that they abide by the fundamental procedural rights that are granted to citizens within the scope of application of the directives. This means that in criminal cases Members States will have for example to do their utmost best to make it possible for nationals to have access to: a lawyer (Article 3 Directive 2013/48/EU), physical presence and participation of a lawyer during questioning (Article 3 (b) Directive 2013/48/EU), the materials of the case (Article 7 Directive 2012/13/EU), interpretation (Article 2 Directive 2010/64/EU), translation of essential documents (Article 3 Directive 2010/64/EU), legal aid (Article 4 Directive 2016/1919/EU) and presence at trial (Article 8 Directive 2016/343/EU). Furthermore, special attention should be paid to the so-called 'vulnerable persons' for which each of these directives explicitly prescribe that "Member States shall ensure that the particular needs of vulnerable persons are taken into account in the application" of the directive in question.

With the challenges that COVID-19 brought, it became clear that some Member States were having a hard time adapting to what was going to be the new normal, being remote access to justice and new ways of organising legal proceedings. It cannot be denied that a lot of Member States were not well enough equipped to deal with these sudden changes. Most of them did not have the right infrastructure in place to deal with the shift from physical to digital, especially when it came to access to materials of a case. Looking at Belgium for example, the situation was and still is that materials of criminal proceedings can only be consulted physically at the court. So when the whole judicial system was shut down due to COVID-19 restrictions and the court registry became only accessible when urgent, the defence in criminal proceedings - concerning people not in detention - became very difficult, if not impossible. 
On top of that, taking into account that hearings were still taking place, an issue of equality of arms arose since only law enforcement was having remote access to materials of a case thanks to an internal digital system that is only accessible by the courts and the prosecutor's office.

A Belgian lawyer rightly put it like this: "While the magistrates of the public prosecutor's office work, for the most part at home, on the preparation of these files, there is nothing we can do. As a result, once the coronavirus crisis is behind us, we are going to end up with a whole series of postponed files, new fixations, files prepared by the magistrates whereas on the defence side, they won't be. It is a system that creates great inequality" [16].

This issue of postponement of files and hearings also brings in another element of EU law: what with the principle of having a fair and public hearing within a reasonable time as covered by the right to a fair trial (Article 47 of the Charter)?

\section{The application of the Charter of Fundamental Rights of the European Union}

The protection under the Charter comes into play in areas in which EU law rights are engaged (Article 51 of the Charter) [11, 15], such as cross-border cases and situations dealing with the implementation of the Roadmap directives. The rights under the Charter might well be impacted by the decisions that Members States have been making by closing courts thereby making filing of documents, access to legal aid, gathering of evidence, and public hearings impossible or extremely difficult [26]. Moreover, courts are organising hearings in different ways and limiting the cases to urgent ones while postponing others. Such restrictions on access to justice and documents, and operations of the courts in general, self-evidently carry the inherent risk of limiting the fundamental rights of EU citizens.

Pursuant to Article 47 of the Charter each individual has the right to an effective remedy and fair trial. These rights do not only entail access to a lawyer, legal aid, translation or interpretation, but equally the right to be present at trial in criminal proceedings [6]. Technology has been frequently relied upon by the Member States to organise hearings on a remote basis to limit the spread of the virus. However, as the European Union Agency for Fundamental Rights already pointed out in its bulletin, if these remote hearings are considered to be the default rule, there could be a negative impact on the minimum standards of suspects and accused as developed under Article 47 of the Charter, in particular in relation to effective participation in proceedings, including one's right to be present at trial and access to adequate facilities for the review of evidence [23]. Furthermore, some reports show that suspects and lawyers have not been able to exchange confidentiality before, during or after a remote hearing given the possible presence of court or prison staff at either end, as well as time constraints [22]. In addition, suspension of non-urgent cases and the inequality of arms in countries like Belgium will also impact the overall length of proceedings and consequently due process, defence rights and the right to liberty contained in Article 6 of the Charter.

The effects on fundamental rights are also visible in civil proceedings where the same issues arise, especially in cases relating to family matters and minors where 
also the right to respect for private and family life (Article 7 of the Charter) and the rights of the child (Article 24 of the Charter) come into play.

\subsection{The justification of national restrictions on fundamental rights under Article 52 of the Charter}

Even though statutes of the Charter concern fundamental rights, they are not absolute. Even prior to the establishment of the Charter, the Court of First Instance (Third Chamber) stated that "fundamental rights, however, do not constitute unfettered prerogatives but may be restricted" [10]. This statement was later codified and expanded on in Article 52(1) of the Charter. Pursuant to Article 52(1) of the Charter "any limitation on the exercise of the rights and freedoms recognised by this Charter must be provided for by law and respect the essence of those rights and freedoms. Subject to the principle of proportionality, limitations may be made only if they are necessary and genuinely meet objectives of general interest recognised by the Union or the need to protect the rights and freedoms of others".

Several requirements for limiting the fundamental rights stated in the Charter may be identified from Article 52 of the Charter. The requirements for limiting the fundamental rights of the Charter largely correspond with the requirements for limiting fundamental rights in national legislation and international human rights conventions [24]. The requirements for limitation contain the following aspects: the statutes of the Charter may be limited if:

1. the limitation is provided by law;

2. the provided law is clear and exact;

3. essence of the statute of the Charter is respected;

4. the limitation of the Charter genuinely meets objectives of general interest recognised by EU or the need to protect the rights and freedoms of others;

5. the limitation to the Charter is necessary and proportionate; and

6. the limitation to the Charter is in compliance with the European Convention for the Protection of Human Rights and Fundamental Freedoms [1, 24].

\subsection{The application of the different requirements to the national restrictions}

In many EU Member States the limitations to fundamental rights have been provided by clear and exact laws. For example, in Finland, the exercising of the Emergency Powers Act (1552/2011, as amended) provides significant restrictions to fundamental rights, some of which are also included in the Charter. The limitations are established with clear and precise sections of the law. Thus, it may be stated that the first and the second requirement for limitations of fundamental rights are not likely to constitute an issue in light of exercising Article 52 of the Charter.

The third requirement requires that the limitation respects the essence of the statute of the Charter. A fundamental right may not be limited to the extent that would render the fundamental right completely insignificant [24]. This requirement has been recently exercised in the Digital Rights Ireland-judgment, in which the CJEU held that the retention of data did not adversely affect the essence of the fundamental right to the protection of personal data because the relevant directive established certain 
principles of data protection and data security to be respected by providers of publicly available electronic communications services or of public communications networks [13]. Thus it was resolved that the right to privacy was not rendered completely insignificant.

The legislation, through which the Member States have implemented limitations to access to justice must limit the access to justice-article of the Charter without rendering it completely insignificant. This means that, as in the Digital Rights Ireland-case, certain principles of the access to justice-article must be upheld even if the access to justice-article is being limited. In Finland access to justice has been limited due to extensive shutdowns of courthouses. However, the Finnish legislation provides a possibility to host the proceedings virtually (Chap. 8, Sect. 13 of the Criminal Procedure Act and Chap. 5 Section 15d of the Code of Judicial Procedure), which has limited the damage to the access to justice-article [28]. Thus it could be stated that the access to justice-article of the Charter has in Finland been limited in a way, which does not render the access to justice-article completely insignificant.

The fourth requirement requires that the limitation of the Charter genuinely meets objectives of general interest recognised by the EU or the need to protect the rights and freedoms of others. A limitation of the Charter may thus be implemented in order to protect a fundamental right protected under EU law for example in the Charter. Furthermore, the limitation may be justified by protecting a general interest recognised by the EU such as public policy, security or health [24]. Public health, as an important general interest of the EU, has been codified in many of the EU's most significant conventions and treaties. For instance, the Treaty on the Functioning of the European Union [4] states that a high level of human health protection shall be ensured in the definition and implementation of all EU policies and activities. Furthermore, the CJEU has in its judgments considered that the objective of the protection of the health and life of humans ranks foremost among the assets or interests protected by Article 36 TFEU [14]. Articles 6 and 35 of the Charter provide further protection to public health as a fundamental right. As the COVID-19 pandemic is foremost a health crisis, it may be stated that the limitations to the fundamental rights provided by the Charter meet the objective of protecting both a general interest recognised by the EU and rights and freedoms of others by preventing the spread of the virus and thus causing more extensive public health issues.

The fifth requirement requires that the limitation is necessary and proportionate in order to achieve the acceptable goal of the limitation. On the principle of proportionality, the CJEU has regularly stated that the measures adopted by EU institutions do not exceed the limits of what is appropriate and necessary in order to attain the objectives legitimately pursued by the legislation in question. Furthermore, when there is a choice between several appropriate measures, recourse must be taken to the least onerous measure [12]. Same rules on proportionality may be applied to the limitations on fundamental rights presented in the Charter.

All limitations on, for example, access to justice must not exceed what is appropriate and necessary in order to safeguard public health. Further, all limitations must be the least onerous measures available. As stated before, many states have shut down entire court systems to prevent the spread of COVID-19. As social distancing has been found - based on current available information - to be the most effective way 
of preventing the spread, the shutdowns may be construed to be the most effective measure to prevent the spread of the virus and thus protect public health. Whether there were less onerous measures available, is still unclear, as there is very little information available on the virus.

The requirements for limiting the fundamental rights of the Charter largely correspond with the requirements for limiting fundamental rights in national legislation and international human rights conventions [24]. Therefore, the sixth requirement shall not be separately discussed in this paper.

\section{Non-jurisdictional remedies under EU law}

The awareness of the potential of Alternative Dispute Resolution mechanisms (hereby referred to as ADR) and the increasing interest shown in the Member States of the EU in order to improve the access to justice, has led to adopting regulations in this matter.

The identification of ADR has caught the attention of experts even since 1987, when at the initiative of the European Commission, in order to harmonize national legislation in the field of civil procedural law and to develop a European model code of civil procedure, a study has been prepared [29].

On a general approach, the main mechanisms of non-jurisdictional remedies are represented by: arbitration, mediation, negotiation, conciliation, the Ombudsman or consumer complaints platforms. These methods benefit from growing recognition, support and acceptance.

ADR remedies generally share a common goal, namely the management of disputes more effectively than contradictory procedures. However, they differ considerably in structure, framework, clientele, staff, size, relationship with the judiciary, sources of funding, objectives or intermediate methods.

Among the factors that have determined the development of alternative methods of dispute resolution are the increase in the number of disputes before the courts, the increasing length of court proceedings, the increase in procedural costs, as well as the high volume and complexity of the legislation which makes it more likely for access to justice to become difficult. To all these, the effects of the COVID-19 pandemic shall be added as in most of the countries the activities of the courts have been either suspended or limited.

\subsection{ADR for consumer law disputes}

It should be noted from the outset that arbitration, as an alternative method of dispute resolution, has not, at least so far, been the subject of regulation of Community legal instruments adopted in international civil proceedings.

Until the adoption of the first Community legal instrument on alternative dispute resolution procedures, namely Directive 2008/52/EC [2], efforts have been made in order to encourage access to such procedures in particular areas, such as consumer protection, family law and employment law.

The initial concerns have been initially focused on consumer protection and in particular on the settlement of foreign disputes. 
In addition to the problems inherent in national judicial dispute resolution proceedings (the high level of legal representation and assistance costs, the complexity and formalism of some legal proceedings) with the intensification of cross-border consumer transactions, the development of new sales techniques, and the existence of risks and barriers to access to justice in cases of foreign disputes, the need to identify these ADR has become more obvious.

The regulatory scope of Directive 2008/52/EC is, in principle, limited to procedural provisions on the relationship between mediation and judicial proceedings.

Its objective pursued is clearly stated in recital 7 of the preamble, according to which, "in order to promote further the use of mediation and ensure that parties having recourse to mediation can rely on a predictable legal framework, it is necessary to introduce framework legislation addressing, in particular, key aspects of civil procedure".

The provisions of Directive 2008/52/EC are applicable in all cases where the court may, in accordance with national law, invite the parties to resort to mediation, as well as where national law provides for this ADR method.

According to recital 13 in the preamble to Directive 2008/52/EC, mediation is conceived as "a voluntary process in the sense that the parties are themselves in charge of the process and may organise it as they wish and terminate it at any time. However, it should be possible under national law for the courts to set time-limits for a mediation process. Moreover, the courts should be able to draw the parties' attention to the possibility of mediation whenever this is appropriate as a voluntary procedure, with the parties having the opportunity to establish the procedure applicable to mediation and being able to use this alternative method of dispute resolution at any time".

Mediation as an ADR method should not be considered an inferior solution to the judicial procedure due to the fact that the observance of the clauses agreed by the parties through the agreement concluded as a result of the completion of the mediation procedure would depend on their will.

Also, it is important to outline that starting from this year, as the Regulation 2019/1150 [7] has entered into force, a new obligation has been imposed for the providers of online intermediation services. Therefore, they shall identify at least two public or private mediators with which they are willing to engage. This shall lead to a new chapter in the applicability of ADR mechanisms.

\subsection{ADR for consumer family and labour law disputes}

In the field of family law, the EU has also introduced some legislative solutions to facilitate the promotion of alternative dispute resolution. We consider, first of all, the provisions of Article 55 lit. e) of the Council Regulation (EC) No 2201/2003 of 27 November 2003 concerning jurisdiction and the recognition and enforcement of judgments in matrimonial matters and the matters of parental responsibility (hereby referred to as Regulation 2201/2003), according to which the central authorities of the Member States active in order to ensure the effective exercise of parental responsibility, at the request of a central authority of another Member State or the holder of parental responsibility, have the obligation to facilitate the conclusion of agreements between the holders of parental responsibility, through mediation or other means. 
The laws of most Member States provide for alternative methods of resolving conflicts of interests or rights, individual or collective, in the field of labour law. These alternative procedures are organised either by the social partners or by public institutions.

Conciliation institutions and mediation or arbitration services have been set up in most Member States, which, as a rule, have an autonomous status.

\subsection{Online dispute resolution platforms}

As key players in the internal market, consumers are constantly catching the attention of the European legislator. The increase in the number of online transactions and also the need to increase the confidence of consumers and traders has led to the shaping of a digital dimension of the internal market and to the creation of a regulatory framework for out-of-court settlement of cross-border disputes in an online environment.

To this end, the European Commission has created the European online dispute resolution platform (SOL platform). This innovative digital tool facilitates the independent, impartial, transparent, effective, expeditious, equitable and out of court settlement of disputes concerning contractual obligations arising out of contracts for the sale or provision of online services between a consumer residing in the Union and a trader established in the Union. The legal basis for the establishment of the ODR platform is Regulation on consumer ODR [5].

The Consumer SOL Regulation describes the main functions of the platform and the steps a complaint must go through. And in the case of choosing to settle a dispute by accessing the ODR platform, the invoked regulatory framework transposes the usefulness of encouraging consumers by Member States to contact the trader in any appropriate way, in order to settle the dispute amicably, before submitting the complaint through the new platform.

The SOL platform takes the form of an interactive website, [30] free of charge and available online in all official languages of the Union institutions, which provides a single point of entry for consumers and traders seeking out-of-court settlement of disputes arising from online transactions. The SOL platform allows consumers and traders alike to submit complaints by completing an electronic complaint form and attaching relevant documents. A trader's complaint against the consumer may be initiated on the ODR platform only to the extent that the law of the Member State in which the consumer has his habitual residence allows such disputes to be settled by the intervention of an ADR entity.

However, this platform shall not replace the possibility for the parties to appeal to the courts, a procedure that is usually more expensive and longer.

In order to facilitate consumer access to information on the ODR platform and the possibility to use it to resolve disputes with traders, the European legislator has imposed on traders established in the Union, which conclude sales or service contracts online, the obligation to provide on their web pages an electronic link to the SOL platform, as well as to specify their e-mail addresses. 


\section{Conclusion}

According to Article 4(3) TEU "the Member States shall take any appropriate measure, general or particular, to ensure fulfilment of the obligations arising out of the Treaties or resulting from the acts of the institutions of the Union. The Member States shall facilitate the achievement of the Union's tasks and refrain from any measure which could jeopardise the attainment of the Union's objectives". This would mean that the national measures taken by the Member States in light of the COVID-19 crisis should be in conformity with the Treaty provisions and secondary EU legislation. Member States should thus question their actions and take into account the measures that the EU has already taken in cross-border cases as well as the procedural safeguards adopted following the Roadmap of 2009. Furthermore, once EU law applies, the fundamental rights enshrined in the Charter apply, most importantly the right to an effective remedy, fair trial, liberty, respect for private and family life, and the rights of the child.

Restricting these fundamental rights without a careful balancing exercise can seriously endanger the rights of EU citizens under EU law. At the moment it is however impossible to assess whether each limitation of the rights in the Charter, implemented by Member States, complies with all the requirements for a justified limitation, without having a thorough knowledge of each jurisdictions legislation and legislative system. It may however be stated that, as public health - as a general principle - is of great importance and highly valued in EU, it is likely that the measures undertaken to protect public health do meet the requirements for limiting the fundamental rights provided in the Charter. Each measure does however require a thorough assessment especially from a proportionality point of view, in order not to extensively restrict one fundamental right on the account of another fundamental right. This assessment should be made in each member state as COVID-19 measures are legislated and implemented.

In what concerns the non-jurisdictional remedies under EU law, we shall conclude that the diversity of ADR mechanisms does not deprive the parties of their right to bring an action in court to resolve the dispute. The right to an effective remedy and to a fair trial are fundamental rights enshrined in Article 47 of the Charter of Fundamental Rights of the European Union. The extrajudicial settlement options have not been designed to replace judicial proceedings and do not deprive the parties to the conflict of the right to seek redress before the courts.

If up to this year when it came to settling a dispute the tendency would have been to opt for a court procedure, individually or in the form of collective lawsuits, the effects of the COVID-19 pandemic may represent a turning point in the matter of settling at least some types of disputes. Consequently, for a better spread of access to alternative mechanisms, it is necessary to increase the level of public awareness of the existence of these options, as well as educating the public in the field, facilitating access to such methods and, possibly, imposing the obligation to use certain such tools in resolving disputes.

Author Contribution This article is based on the contribution submitted by the winning team in the 2021 Young Lawyers Contest organised by ERA and the Warsaw Bar in cooperation with the CCBE. 


\section{References}

1. European Convention for the Protection of Human Rights and Fundamental Freedoms (ETS No.005)

2. Directive 2008/52/EC of the European Parliament and of the Council of 21 May 2008 on certain aspects of mediation in civil and commercial matters

3. Resolution of the Council of 30 November 2009 on a Roadmap for strengthening procedural rights of suspected or accused persons in criminal proceedings. Off. J. Eur. Union C 295 (2009)

4. Treaty on the Functioning of the European Union, Off. J. Eur. Union C 326 26/10/2012, P. 0001-0390

5. Regulation (EU) No 524/2013 of the European Parliament and of the Council of 21 May 2013 on online dispute resolution for consumer disputes and amending Regulation (EC) No 2006/2004 and Directive 2009/22/EC

6. Directive (EU) 2016/343 of the European Parliament and of the Council of 9 March 2016 on the strengthening of certain aspects of the presumption of innocence and of the right to be present at the trial in criminal proceedings. Off. J. Eur. Union L 65 (2016)

7. Regulation (EU) 2019/1150 of the European Parliament and of the Council of 20 June 2019 on promoting fairness and transparency for business users of online intermediation services

8. Case C-26/62, Van Gend en Loos, ECLI:EU:C:1963:1

9. Case C-41/74, Van Duyn, ECLI:EU:C:1974:133

10. Case T-176/94, Kv Commission of the European Communities, ECLI:EU:T:1995:139, para. 33

11. Case C-292/97, Kjell Karlsson and Others, ECLI:EU:C:2000:202, para. 37

12. CJEU, C-343/09, Afton Chemical ECLI:EU:C:2010:419, para. 45

13. CJEU, C-615/10, Digital Rights Ireland, ECLI:EU:C:2014:238, para. 40

14. CJEU, C-333/14, Scotch Whiskey Association, ECLI:EU:C:2015:845, para. 35

15. Case C-220/20 XX v. OO, ECLI:EU:C:2020:1022, para. 35-37, 43

16. Bensalem, N.: L'avocate Nathalie Gallant pousse un coup de gueule: «Si le ministre ne nous laisse pas travailler via JustScan, la situation sera catastrophique par la suite » (2020). Available at: https://www.dhnet.be/actu/belgique/l-avocate-nathalie-gallant-pousse-un-coup-de-gueule-sile-ministre-ne-nous-laisse-pas-travailler-via-justscan-la-situation-sera-catastrophique-par-la-suite$5 \mathrm{e} 7 \mathrm{c} 5 \mathrm{~d} 3 \mathrm{e} 9978 \mathrm{e} 228414234 \mathrm{c} 0$

17. Bux, U.: Judicial cooperation in criminal matters (2020). Available at: https://www.europarl.europa. eu/factsheets/en/sheet/155/judicial-cooperation-in-criminal-matters

18. Craig, P., De Burca, G.: EU Law: Text, Cases and Materials, 7th edn. Oxford University Press, Oxford (2020), p. 1064

19. Fairhurst, J.: Law of the European Union, 11th edn. Pearson, Harlow (2016), p. 27-28

20. FairTrials: Short update: Council of European Union publishes information on impact of COVID-19 on cooperation in criminal matters (2020). Available at: https://www.fairtrials.org/news/short-updatecouncil-european-union-publishes-information-impact-COVID-19-cooperation-criminal

21. FairTrials: Short Update: UK High Court rules detention pending surrender under EAW is lawful even if extradition cannot take place temporarily due to COVID-19 (2020). Available at: https://www. fairtrials.org/news/short-update-uk-high-court-rules-detention-pending-surrender-under-eaw-lawfuleven-if

22. FairTrials: Safeguarding the right to a fair trial during the coronavirus pandemic: remote criminal justice proceedings (2020). Available at: https://www.fairtrials.org/news/safeguarding-right-fair-trialduring-coronavirus-pandemic-remote-criminal-justice-proceedings

23. FRA: Coronavirus pandemic in the EU - Fundamental Rights Implications - Bulletin 1 (2020). Available at: https://fra.europa.eu/sites/default/files/fra_uploads/fra-2020-coronavirus-pandemic-eubulletin_en.pdf

24. Ojanen, T.: EU-oikeuden perusteita, 3rd edn. (2016), p. 164-166

25. Riehle, C., Clozel, A.: 10 years after the roadmap: procedural rights in criminal proceedings in the EU today (2019). Available at: https://link.springer.com/Article/10.1007/s12027-019-00579-5

26. Shabbir, A.: Access to justice and COVID-19 related state of emergency: litigation before the Court of Justice (2020). Available at: https://eulawlive.com/access-to-justice-in-cross-border-casesand-COVID-19-related-state-of-emergency-litigation-before-the-court-of-justice/

27. European arrest warrant. Available at: https://ec.europa.eu/info/law/cross-border-cases/judicialcooperation/types-judicial-cooperation/european-arrest-warrant_en\#proportionality

28. Tuomioistuinviraston opas tuomioistuimille etäyhteyksien käyttöön oikeudenkäynnissä (unofficial translation: Guide on the use of virtual means of communication in court procedures by the National Courts Administration of Finland). Accessible at: https://tuomioistuinvirasto.fi/ 
en/index/ajankohtaista/2020/thenationalcourtsadministrationgaveinstructionsonremotesessionstheaimistolowerthethreshold.html

29. de Storme, M.L.: Rapprochement du Droit Judiciaire de l'Union Européenne. Approximation of Judiciary Law in the European Union. Kluwer Academic, Dordrecht (1994)

30. Online Dispute Resolution. Available at: https://webgate.ec.europa.eu/odr/main/?event=main.home. show\&lng=RO

Publisher's Note Springer Nature remains neutral with regard to jurisdictional claims in published maps and institutional affiliations. 